\title{
Hubungan Karakteristik Ibu dengan Status Gizi Balita di Desa Tanjung Gunung Bangka Tengah Tahun 2017
}

\author{
Endriyani Martina Yunus \\ Jurusan Gizi Poltekkes Kemenkes Pangkalpinang \\ Email : endriyani_my@yahoo.com
}

\begin{abstract}
Abstrak
Permasalahan gizi di Indonesia salah satunya adalah gizi kurang yang disebabkan oleh beberapa faktor diantaranya adalah karena jumlah asupan pangan yang bermutu, factor lingkungan, tingkat pendidikan, social ekonomi, dan adanya factor infeksi (penyakit). Penelitian ini bertujuan Mengetahui Hubungan Karakteristik Ibu dengan Penilaian Status Gizi Balita di desa tanjung gunung kabupaten Bangka Tengah tahun 2017. Jenis atau desain penelitian ini adalah desain analitik. Metode pengumpulan data yang dilakukan dalam penelitian ini adalah purposive sampling. Sampel penelitian ini adalah ibu dan balita ( 99 orang). Hasil penelitian ini menunjukkan 27 (27,3\%) dengan gizi kurang, 16 (16,2\%) dengan umur beresiko, $80(80,8 \%)$ dengan pendidikan rendah, $10(10,1 \%)$ dengan kategori ibu bekerja, dan 29 responden $(29,3 \%)$ dengan pengetahuan kurang. Berdasarkan hasil analisis bivariat dengan $p$-value $<0,05$, yang menunjukkan bahwa ada hubungan antara pendidikan dengan penilaian status gizi balita. Berdasarkan hasil analisis multivariat, variabel yang paling dominan mempengaruhi penilaian status gizi adalah pendidikan. Tenaga kesehatan lebih memotivasi ibu yang memiliki balita untuk rutin membawa balitanya untuk di timbang ke posyandu, dan tenaga kesehatan diharapkan selalu memberikan pendidikan kesehatan mengenai kebutuhan gizi balita.
\end{abstract}

Kata kunci $\quad$ : Pendidikan, Status Gizi, Balita

\section{Relationship Characteristics of Mother With Nutrition Status of Toddlers in Tanjung Gunung Village Bangka Tengah, 2017}

\begin{abstract}
Nutrition problems in Indonesia one of them is less nutrition caused by several factors such as the amount of food intake of quality, environmental factors, education level, social economy, and the existence of infection factor (disease). This study aims to determine the Relationship Characteristics of Mother with Nutritional Status of Toddlers in the village of Mount Tanjung district of Central Bangka in 2017. Type / design of this study is analytic. Data collection method that done in this research is purposive sampling. Sample of this study were mothers and toddlers (99 people). The results of this study were 27 (27.3\%) with malnutrition, 16 (16.2\%) with age at risk, $80(80.8 \%)$ with low education, 10 (10.1\%) with category working mother, and 29 respondents (29,3\%) with less knowledge. Based on the result of bivariate analysis with p-value <0,05, indicating that there is correlation between education with the assessment of nutritional status of children. Based on the result of multivariate analysis, the most dominant variable influencing the evaluation of nutritional status is education. Health workers are more motivating mothers who have toddlers to routinely bring balitanya to weigh to posyandu, and health workers are expected to always provide health education regarding the nutritional needs of toddlers.
\end{abstract}

Keywords: education, nutritional status, toddlers 


\section{PENDAHULUAN}

Salah satu indikator gizi masyarakat adalah status gizi balita dan bahkan telah dikembangkan menjadi salah satu indikator kesehatan dan kesejahteraan masyarakat. Hal ini dikarenakan kelompok yang sangat rentan terhadap berbagai penyakit adalah bayi dan balita. Proses pertumbuhan dan perkembangan terjadi dengan cepat pada masa balita, dengan hal tersebut balita membutuhkan asupan gizi berkualitas baik dan seimbang, karena pada masa inilah terjadi banyak aktifitas yang tentunya tinggi. Tidak tercapainya pertumbuhan dan perkembangan optimal disebabkan oleh kebutuhan gizi balita yang tidak terpenuhi. Hal tersebut dapat menjadi penyebab masalah kekurangan gizi, yang selanjutnya dapat beresiko menurunkan derajat kesehatan (Depkes RI, 2002).

Terdapat banyak faktor yang mempengaruhi status gizi pada masyarakat. Faktor penting yang mempengaruhi status gizi salah satunya adalah kondisi sosial ekonomi. Status gizi diharapkan semakin baik apabila kondisi sosial ekonominya baik. Status gizi anak balita akan berkaitan erat dengan kondisi sosial ekonomi keluarga (orang tua), antara lain pendidikan orang tua, pekerjaan orang tua, jumlah anak serta kondisi ekonomi orang tua secara keseluruhan (Supariasa, 2014).

Menurut Profil Dinas Kesehatan Provinsi, 2012 di Kabupaten Bangka Tengah cakupan gizi buruk pada balita $(0,05 \%)$ yang mendapatkan perawatan terdiri dari 4 balita jenis kelamin laki-laki, dan 2 balita jenis kelamin perempuan, sedangkan jumlah balita yang ditimbang dengan kondisi bawah garis merah $(1,1 \%)$ terdapat 53 balita jenis kelamin laki-laki, dan 71 balita jenis kelamin perempuan.

Menurut Profil Dinas Kesehatan Bangka Tengah, 2014 terdapat kasus balita gizi buruk untuk 8 (delapan) puskesmas pada tahun 2014 sebanyak 9 kasus yang disertai penyakit penyerta diantaranya kelainan jantung, TB anak, dan semua mendapat perawatan baik rawat inap maupun rawat jalan. Angka ini dibandingkan dengan tahun 2013 terjadi penurunan yaitu kasus gizi buruk tahun 2013 ada 12 kasus.

Tujuan penelitian ini untuk mengetahui hubungan Mengetahui Hubungan Karakteristik Ibu dengan Penilaian Status Gizi Balita di desa tanjung gunung kabupaten Bangka Tengah tahun 2017.

Manfaat penelitian ini diharapkan dapat menambah wawasan ilmu pengetahuan tentang Penilaian Status Gizi Balita dalam rangka deteksi dini permasalahan gizi (gizi kurang, gizi buruk dan gizi lebih) dan Hasil penelitian merupakan salah satu upaya mencapai pertumbuhan dan perkembangan yang optimal, serta meningkatkan derajat kesehatan masyarakat melalui asupan gizi yang berkualitas baik dan seimbang.

\section{METODE}

Jenis / desain penelitian ini adalah deskriptif analitik. Sampel dalam penelitian ini menggunakan total populasi adalah ibu dan balita yang datang ke Posyandu di Desa Tanjung Gunung tahun 2017 sebanyak 99 balita. Penelitian ini menggunakan teknik pengambilan sampel secara purposive sample dengan menggunakan data primer, memberikan kuisioner dan wawancara terhadap responden.

\section{HASIL}

\section{Karakteristik Ibu dan Penilaian Status Gizi Balita}

Tabel 1 Distribusi Responden

Berdasarkan Karakteristik Ibu dengan

Penilaian Status Gizi Balita

\begin{tabular}{lcc}
\hline \multicolumn{1}{c}{ VARIABEL } & n & \% \\
\hline Penilaian Status Gizi & & \\
\hline Gizi Kurang & 27 & 27,3 \\
\hline Gizi Baik & 72 & 72,7 \\
\hline Total & 99 & 100 \\
\hline Umur Ibu & & \\
\hline Beresiko & 16 & 16,2 \\
\hline Tidak Beresiko & 83 & 83,8 \\
\hline Total & 99 & 100 \\
\hline Pendidikan & & \\
\hline Rendah & 80 & 80,8 \\
\hline Menengah & 17 & 17,2 \\
\hline Tinggi & 2 & 2,0 \\
\hline Total & 99 & 100 \\
\hline Pekerjaan & & \\
\hline Tidak Bekerja & 89 & 89,9 \\
\hline Bekerja & 10 & 10,1 \\
\hline Total & 99 & 100 \\
\hline Pengetahuan & & \\
\hline Baik & 37 & 37,4 \\
\hline Cukup & 33 & 33,3 \\
\hline Kurang & 29 & 29,3 \\
\hline Total & 99 & 100 \\
\hline
\end{tabular}


Hasil ini menggambarkan distribusi responden, diketahui bahwa terdapat 27 responden $(27,3 \%)$ dengan gizi kurang, 16 responden $(16,2 \%)$ dengan umur beresiko, 80 responden $(80,8 \%)$ dengan pendidikan rendah, 10 responden $(10,1 \%)$ dengan kategori ibu bekerja, dan 29 responden $(29,3 \%)$ dengan pengetahuan kurang.

\section{Hubungan Karakteristik Ibu dengan Penilaian Status Gizi Balita}

Tabel 2 Hubungan Karakteristik Ibu dengan Penilaian Status Gizi Balita

\begin{tabular}{|c|c|c|c|c|c|c|c|c|}
\hline \multirow[t]{3}{*}{ Variabel } & \multicolumn{4}{|c|}{ Gizi } & \multirow{2}{*}{\multicolumn{2}{|c|}{ Total }} & \multirow{3}{*}{$\begin{array}{c}p- \\
\text { value }\end{array}$} & \multirow[t]{3}{*}{ OR } \\
\hline & \multicolumn{2}{|c|}{ Kurang } & \multicolumn{2}{|c|}{ Baik } & & & & \\
\hline & n & $\%$ & $\mathrm{n}$ & $\%$ & $\mathbf{N}$ & $\%$ & & \\
\hline Umur Ibu & & & & & & & 0,362 & 1,771 \\
\hline Beresiko & 6 & 37,5 & 10 & 62,5 & 45 & 100 & & \\
\hline $\begin{array}{l}\text { Tidak } \\
\text { Beresiko }\end{array}$ & 21 & 25,3 & 62 & 74,7 & 63 & 100 & & \\
\hline Total & 27 & 27,3 & 72 & 72,7 & 108 & 100 & & \\
\hline Pendidikan & & & & & & & 0,026 & - \\
\hline Rendah & 18 & 22,5 & 62 & 77,5 & 80 & 100 & & \\
\hline Menengah & 9 & 52,9 & 8 & 47,1 & 17 & 100 & & \\
\hline Tinggi & 0 & 0 & 2 & 2 & 2 & 100 & & \\
\hline Total & & & & & & 100 & & \\
\hline Pekerjaan & & & & & & & 0,278 & 0,269 \\
\hline $\begin{array}{l}\text { Tidak } \\
\text { Bekerja }\end{array}$ & 26 & 29,2 & 63 & 70,8 & 89 & 100 & & \\
\hline Bekerja & 1 & 10 & 9 & 90 & 10 & 100 & & \\
\hline Total & 27 & 27,3 & 72 & 72,7 & 99 & 100 & & \\
\hline $\begin{array}{l}\text { Pengetahua } \\
\text { n }\end{array}$ & & & & & & & 0,300 & - \\
\hline Kurang & 8 & 21,6 & 29 & 78,4 & 37 & 100 & & \\
\hline Cukup & 8 & 24,2 & 25 & 75,8 & 33 & 100 & & \\
\hline Baik & 11 & 37,9 & 18 & 62,1 & 29 & & & \\
\hline Total & & & & & & 100 & & \\
\hline
\end{tabular}

Berdasarkan hasil analisis bivariat dengan $p$ value $<0,05$, yang menunjukkan bahwa ada hubungan antara pendidikan dengan penilaian status gizi balita.

\section{Analisis Multivariat}

Berdasarkan hasil analisis multivariat, variable yang paling dominan mempengaruhi penilaian status gizi adalah pendidikan.

\section{PEMBAHASAN}

\section{Penilaian Status Gizi}

Berdasarkan hasil penelitian didapat hasil penilaian status gizi dengan kategori gizi kurang yaitu, sebagian kecil balita dengan status gizi kurang yaitu 27 balita $(27,3 \%)$.

Masalah gizi kurang biasanya disebabkan oleh kemiskinan, kurangnya ketersediaan pangan, sanitasi lingkungan yang tidak baik, kurangnya pengetahuan masyarakat tentang gizi, dan adanya daerah miskin gizi (Almatsier S, 2004).

Pertumbuhan anak sangat berpengaruh terhadap konsumsi makanan sehingga mempengaruhi terhadap status gizi anak. Status gizi baik terjadi bila tubuh memperoleh cukup zat-zat gizi yang di gunakan secara efisien sehingga memungkinkan pertumbuhan fisik, perkembangan otak, kemampuan kerja dan kesehatan secara umum.

\section{Umur Ibu}

Berdasarkan hasil penelitian menunjukan bahwa sangat sedikit ibu dengan kategori umur beresiko, yaitu terdapat $16 \mathrm{ibu}(16,2 \%)$ ibu dengan umur beresiko (umur ibu kurang dari 20 tahun dan lebih dari 35 tahun).

Hasil analisis bivariat menunjukkan tidak ada hubungan antara umur ibu dengan penilaian status gizi balita. Dalam penelitian ini ibu dengan umur beresiko (<20tahun dan $>35$ tahun) memiliki persentase kejadian gizi kurang $(37,5 \%)$ dibanding dengan status gizi baik. Hal ini bisa terjadi karena faktor lain yaitu faktor pengetahuan $\mathrm{ibu}$, dimana pada penelitian ini umur ibu masih tergolong umur kehamilan muda, bisa dikarenakan kurangnya pengetahuan ibu tentang gizi, faktor umur juga sangat mempengaruhi tingkat pengetahuan ibu tentang gizi, jadi umur ibu yang masih muda, belum memiliki banyak pengetahuan yang cukup mengenai gizi, baik ibu pada saat hamil maupun pasca melahirkan (Daryono, 2003 dalam Liswati 2016).

Umur untuk wanita hamil yaitu antara 20-35 tahun. Tetapi dalam kenyataannya masih banyak wanita yang melahirkan dibawah 20 tahun dengan status gizi balita normal. Hal ini dikarenakan faktor kesungguhan ibu dalam merawat, mengasuh serta membesarkan anaknya. Sikap dan pengetahuan tentang gizi anak yang cukup akan memberikan dampak pada pola pemberian makan yang diberikan kepada anak balita sehingga berpengaruh pada status gizi balita (Unicef, 2002).

Ibu dengan umur tidak beresiko mempunyai peluang 1,7 kali memiliki 
balita dengan gizi baik dibanding dengan umur ibu yang beresiko. hal ini dikarenakan umur merupakan salah satu faktor yang dapat menggambarkan kematangan seseorang artinya dalam hal kematangan pembentukan pola konsumsi makanan yang berpengaruh terhadap status gizi.

\section{Pendidikan}

Berdasarkan hasil penelitian menunjukan bahwa hampir seluruhnya ibu dengan pendidikan rendah yaitu 80 ibu $(80,8 \%)$. Hasil analisis bivariat menunjukkan ada hubungan antara pendidikan dengan penilaian status gizi balita.

Menurut Haryani, 2011 dalam Khotimah, Kuswandi, 2014 menyatakan bahwa pendidikan merupakan salah satu poin penting dalam kehidupan terutama pendidikan kesehatan gizi sangat diperlukan untuk membentuk perilaku positif dalam hal memenuhi kebutuhan gizi sebagai salah satu unsur penting yang mendukung status kesehatan seseorang, pendidikan gizi dilakukan untuk menghasilkan perilaku yang dibutuhkan untuk memelihara, mempertahankan, ataupun meningkatkan keadaan gizi baik terutama gizi balita.

Tingkat pendidikan seseorang akan berkaitan erat dengan wawasan pengetahuan mengenai sumber gizi dan jenis makanan yang baik untuk konsumsi keluarga. Ibu rumah tangga yang berpendidikan akan cenderung memilih makanan yang lebih baik dalam mutu dan jumlahnya, dibanding dengan ibu yang pendidikan lebih rendah (Meryana, 2014).

Hasil analisis multivariat menunjukkan bahwa pendidikan merupakan variabel yang paling dominan berhubungan dengan penilaian status gizi balita.

Seseorang yang hanya tamat sekolah dasar belum tentu kurang mampu menyusun makanan yang memenuhi persyaratan gizi dibandingkan orang lain yang pendidikannya tinggi, karena walaupun pendidikannya rendah, jika orang tersebut rajin mendengarkan penyuluhan gizi bukan mustahil pengetahuan gizinya akan lebih baik.
Hanya saja tetap harus dipertimbangkan bahwa faktor tingkat pendidikan turut pula menentukan mudah tidaknya seseorang menyerap dan memahami pengetahuan gizi yang mereka peroleh.

\section{Pekerjaan}

Berdasarkan hasil penelitian sangat sedikit responden ibu bekerja yaitu $10 \mathrm{ibu}$ $(10,1 \%)$.

Hasil analisis bivariat menunjukkan tidak ada hubungan antara pekerjaan dengan penilaian status gizi, dan dapat disimpulkan bahwa ibu tidak bekerja mempunyai peluang 0,358 kali memiliki balita dengan gizi baik dibandingkan dengan ibu yang tidak bekerja.

Partisipasi tenaga kerja wanita berhubungan langsung dengan reduksi waktu yang disediakan untuk menyusui anak dan merawat anak sehingga mempunyai konsekwensi negatif terhadap gizi anak. Bertambah luasnya lapangan kerja, semakin mendorong banyaknya kaum wanita yang bekerja terutama di sektor swasta. Di satu sisi hal ini berdampak positif bagi pertambahan pendapatan, namun di sisi lain berdampak negatif terhadap pembinaan dan pemeliharaan anak terutama dalam menjaga asupan gizi balita (Nerlov, 2007 dalam Asima, 2011).

\section{Pengetahuan}

Berdasarkan hasil penelitian sebagian kecil responden dengan pengetahuan kurang $29 \mathrm{ibu}(29,3 \%)$.

Hasil analisis bivariat menunjukkan tidak ada hubungan antara pengetahuan dengan penilaian status gizi.

Kecenderungan seseorang untuk memiliki motivasi berperilaku kesehatan yang baik dipengaruhi oleh tingkat pengetahuan, sikap dan keterampilannya (Emilia, O., 2008).

Apabila penerimaan perilaku didasari oleh pengetahuan, kesadaran dan sikap yang positif maka perilaku tersebut akan berlangsung lama (long lasting) (Notoatmodjo, 2007).

Pengetahuan gizi yang baik diharapkan mempunyai status gizi yang baik pula. Menurut Zulaekah (2011), 
pendidikan mempengaruhi pengetahuan yaitu, dengan memberikan intervensi pendidikan gizi dua minggu sekali dengan alat bantu booklet secara langsung pada siswa, didukung dengan pendidikan gizi pada guru kelas dan orangtua dalam hal ini ibu akan meningkatkan pengetahuan.

Pendapat yang sama juga dinyatakan oleh Talahatu (2006) yaitu, terdapat hubungan positif nyata antara pengetahuan gizi dan kesehatan dengan tingkat pendidikan formal. Makin tinggi tingkat pengetahuan, pendidikan, keterampilan makin baik tingkat ketahanan pangan keluarga, makin baik pola pengasuhan maka akan banyak keluarga yang memanfaatkan pelayanan kesehatan, sehingga diharapkan status gizi baik.

\section{SIMPULAN}

Berdasarkan hasil penelitian terhadap Penilaian Status Gizi Balita di desa Tanjung Gunung Kabupaten Bangka Tengah tahun 2017, maka dapat disimpulkan bahwa ada hubungan antara pendidikan ibu dengan status gizi balita. Tingkat pendidikan merupakan salah satu indikator sosial dalam masyarakat karena melalui pendidikan sikap tingkah laku manusia dapat meningkat dan berubah citra sosialnya. Pendidikan ibu merupakan modal utama dalam menunjang ekonomi keluarga, juga berperan dalam penyusunan makan keluarga serta pengasuhan dan perawatan anak.

\section{SARAN}

Tenaga kesehatan lebih memotivasi ibu yang memiliki balita untuk rutin membawa balitanya untuk di timbang ke posyandu, dan tenaga kesehatan diharapkan selalu memberikan pendidikan kesehatan mengenai kebutuhan gizi balita.

\section{DAFTAR PUSTAKA}

Almatsier S. 2004. Prinsip Dasar Ilmu Gizi. Jakarta: Gramedia Pustaka Utama.

Arif. 2006. Hubungan Antara Karakteristik Ibu dengan Status Gizi Balita di Kelurahan Sekaran Kecamatan Gunungpati Semarang. Dalam online: http://lib.unnes.ac.id/3363/, diakses tanggal 3 November 2017.

Asima, 2011. Jurnal Hubungan Antara Pengetahuan Dan Sikap Orang Tua

Tentang Gizi Dalam Meningkatkan Status Gizi Anak Usia Pra Sekolah Di Wilayah Kerja Puskesmas Sonorejo Sukoharjo. Dalam online:

http://digilib.unimus.ac.id/files/disk1/132/jt ptunimus-gdl-noorrofiqo-6586-2-babi.pdf, diakses tanggal 3 November 2017.

Depkes RI. 2000. Pedoman Tenaga Gizi Puskesmas. Jakarta: Depkes RI.

Depkes RI. 2002. Pemantauan Pertumbuhan Anak. Direktorat Gizi Masyarakat: Jakarta.

Khotimah, Kuwsandi. 2014. Hubungan Karakteristik Ibu dengan Status Gizi Balita di Desa Sumur Bandung Kecamatan Cikulur Kabupaten Lebak. Jurnal Obstetrica Scientia, Vol.2 No. 1 Juni 2014.

Liswati. 2016. Hubungan Karakteristik Ibu dengan Status Gizi Anak Balita yang memiliki Jamkesmas di Desa Tegal Giri Kecamatan Nogosari Kabupaten Boyolali.

Meryana. 2014. Gizi dan Kesehatan Balita. Edisi Pertama, Kencana: Jakarta.

Notoatmodjo, S., 2007. Kesehatan Masyarakat Ilmu dan Seni . Jakarta: PT Rineka Cipta

Profil Dinas Kesehatan Bangka Tengah, 2012

Profil Dinas Kesehatan Bangka Tengah, 2014

Supariasa. (2014) Penilaian Status Gizi. Jakarta : EGC.

Talahatu, A. H., 2006. Kajian Indeks Masa Tubuh (IMT) dan Pertambahan Berat Badan Ibu Hamil serta hubungannya dengan Tumbuh Kembang Bayi Lahir di Kota Ambon. Diakses 3 November 2017. http://repository.ipb.ac.id.

Unicef. 2002. Pedoman Hidup Sehat. Jakarta : Unicef.

Zulaekah, S., 2011. Efektivitas Pendidikan Gizi dengan Media Booklet terhadap Pengetahuan Gizi Anak SD. Diakses 20 Juni 2012. http://journal.unnes.ac.id/index.php/kemas 